\title{
Clinical outcome of post placental copper T380A and copper 375 IUCD insertion in women delivering by caesarean section
}

\section{Divya*, Rupali Dewan}

Department of Obstetrics and Gynecology, Vardhman Mahavir Medical College and Safdarjung Hospital, New Delhi, India

Received: 03 July 2018

Accepted: 02 August 2018

*Correspondence:

Dr. Divya,

E-mail: divambbs@gmail.com

Copyright: (c) the author(s), publisher and licensee Medip Academy. This is an open-access article distributed under the terms of the Creative Commons Attribution Non-Commercial License, which permits unrestricted non-commercial use, distribution, and reproduction in any medium, provided the original work is properly cited.

\begin{abstract}
Background: The objective of the study was to compare the clinical outcome (safety, efficacy, expulsion and continuation rates) of post placental insertion of $\mathrm{Cu} 375$ and CuT380A intrauterine contraceptive devices (IUCD) in primiparous women undergoing caesarean section.

Methods: This was a prospective, randomized comparative study in which 300 primiparous women were recruited. All these women had post placental intracaesarean insertion of CuT 380A or Cu375 IUCD. Follow up visits were scheduled at 1, 3 months, 6 month and 12 months.

Results: Mean age was 23.1 years. Visibility of strings increased in successive follow up visits and was visible in $97.1 \%$ of women at the end of one year and $72.3 \%$ in CuT380A IUCD users at 12 months. Menorrhagia was reported in $8.6 \%$ in Cu375 IUCD users and $10 \%$ in CuT380A IUCD users at the end of 1 year of follow up. There were only 10 expulsions of $\mathrm{Cu} 375$ IUCD and six that of CuT380A IUCD. Removal rate in was $7.3 \%$ in Cu375 users and $6.7 \%$ in CuT380A users. Overall $84.7 \%$ of the women were satisfied with the treatment and $60 \%$ to an extent that they would like to recommend it to others whereas $15.3 \%$ were not satisfied at all either due to adverse events or spontaneous expulsion of IUCD.

Conclusions: The Gross cumulative continuation rates was $86 \%$ in women with Cu375 IUCD insertions and 89.3\% in CuT380A IUCD users. There was no significant difference between Cu375 and CuT380A regarding the safety, efficacy and complications.
\end{abstract}

Keywords: Caesarean, Continuation rate, Expulsion, IUCD

\section{INTRODUCTION}

Short interconceptional period in a woman of caesarean section puts her at increased risk of morbidity, mortality. Immediate post placental insertion of intrauterine contraceptive device (IUCD) is the most cost effective, reversible and effective long-term contraception which does not interfere with breast feeding. ${ }^{1}$

According to the WHO'S medical eligibility criteria recommendations PPIUCD is used in the immediate postpartum period, including intra caesarean has been rated as category. ${ }^{1,2}$ In India Copper $\mathrm{T} 380 \mathrm{~A}$ is being supplied by government of India free of cost in all government health centers and also to private practitioners, nowadays Copper 375 is also being used in National Family Health Program. It is observed that the acceptance of Copper 375 IUCDs for interval contraception is higher as compared to Copper T 380A. ${ }^{3}$ The efficacy of intracaesarean IUCD insertion without any added risk of infectious morbidity has also been reported by various studies. ${ }^{4-7,8}$ This technique offers the 
obstetrician an opportunity to insert the IUCD into the uterus under vision, thus obviating the fear of perforating the uterus during the procedure. The present study was designed to compare the clinical outcomes (efficacy, expulsion and continuation rates) in women undergoing intra caesarean insertion of Copper $\mathrm{T} 380 \mathrm{~A}$ and Copper 375.

\section{METHODS}

This Prospective Randomized Comparative study was conducted in the department of Obstetrics and Gynecology, Vardhman Mahavir Medical College and Safdarjung Hospital, New Delhi from November 2012 to March 2014. This study included 300 women who delivered in this Hospital and divided into two groups, 150 women who had post placental intracaeserean insertion of $\mathrm{Cu} 375$ IUCD and second group Included 150 women who had post placental intracaeserean insertion of CuT380A IUCD.

Women received counselling about PPIUCD insertion while attending ANC clinic, admitted in antenatal ward and in early labour (in labour room). Repeat counselling was done prior to caesarean section and a written, informed consent was taken. She was enrolled for the study only when they agreed for insertion for less than or up to 5 years and were ready to come for follow-up visits post insertion. The insertion of IUCD was done after delivering the baby, using ring forceps, through the uterine incision, and fundal placement of the device was ensured. No attempt was made to direct the IUCD strings towards the internal OS. Antibiotics were administered as per the hospital protocol for caesarean delivery. Women were observed daily for evidence of postpartum MK haemorrhage or sepsis during the entire hospital stay. The participants were asked to return for scheduled follow up visits at 1, 3, 6 and 12 months or earlier in case of any adverse event like pelvic pain, foul smelling vaginal discharge or excessive bleeding. At each visit, a detailed history regarding excessive bleeding, symptoms of infection, abdominal cramps or any other complaint was taken, along with general physical and pelvic examination. If vaginal discharge was present, a wet smear was performed; ultrasonography was done at first visit to ascertain the location of IUCD and at subsequent visits if the IUCD thread was not visible. Data was validated, entered into a computer and statistical analysis was carried out using SPSS version 12. Descriptive data were summarized as percentages or means. Parameters studied were continuation rate of intracaesarean $\mathrm{Cu} T$ $380 \mathrm{~A}$ and Cu375 IUCD. The spectrum of adverse events associated with it, including expulsion, removal and failure rates were compared. Chi square test was used for testing the statistical significance of qualitative variables. Student $\mathrm{t}$ test was used for quantitative variables to evaluate safety, efficacy and acceptability. Life table analysis was used to determine expulsion and discontinuation rates for different group of IUCD users.

\section{RESULTS}

A total of 300 nulliparous women fulfilling WHO Standard Medical Criteria for PPIUCD insertion and willing to comply with the study protocol had post placental intracaesarean insertion of Copper T 380A or Copper 375 IUCD. The Mean age of the study population was 23.1 \pm 2.5 years (Table 1). The demographic and clinical profile of the women is shown in Table 1.

Table 1: Demographic and clinical profile of intracaesarean IUCD acceptors.

\begin{tabular}{|c|c|c|c|c|c|}
\hline \multirow{2}{*}{ Parameters } & \multicolumn{2}{|c|}{ Cu 375 IUCD users } & \multicolumn{2}{|c|}{ CuT380A IUCD users } & \multirow{3}{*}{ P Value } \\
\hline & \multicolumn{2}{|c|}{$\mathrm{n}=150$} & \multicolumn{2}{|c|}{$\mathrm{n}=150$} & \\
\hline Age (Years) & Number & $(\%)$ & Number & $(\%)$ & \\
\hline$\leq 20$ & 14 & 9.3 & 2 & 1.3 & \\
\hline $21-25$ & 95 & 63.3 & 101 & 67.3 & 0.051 \\
\hline $26-30$ & 41 & 27.3 & 47 & 31.3 & \\
\hline Mean age \pm SD & $22.85 \pm 2.59$ & & $23.4 \pm 2.26$ & & $23.1 \pm 2.5$ \\
\hline Socioeconomic status & Number & $(\%)$ & Number & $(\%)$ & \\
\hline Low & 105 & 70 & 110 & 73.3 & \\
\hline Middle & 45 & 30 & 40 & 26.7 & 0.522 \\
\hline Upper & Nil & Nil & Nil & Nil & \\
\hline \multicolumn{6}{|l|}{ Time of counselling } \\
\hline Antenatal period & 47 & 31 & 45 & 30 & \multirow{2}{*}{$<0.05$} \\
\hline Early labour/before LSCS & 103 & 69 & 105 & 70 & \\
\hline \multicolumn{6}{|l|}{ Type of LSCS } \\
\hline Emergency & 130 & 87 & 120 & 80 & \multirow{2}{*}{$<0.05$} \\
\hline Elective & 20 & 13 & 30 & 20 & \\
\hline \multicolumn{6}{|l|}{ Leaking per vaginum } \\
\hline Lpv absent & 40 & 27 & 30 & 20 & \multirow{2}{*}{$<0.05$} \\
\hline Lpvpresent ( $<18$ hours) & 110 & 73 & 120 & 80 & \\
\hline
\end{tabular}


The most commom post insertion complication in both the groups was postoperative febrile morbidity which was not because of pelvic infection (Table 2). Majority of women (94\%) had a hospital stay of less than 4 days.

Table 2: Post insertion complications.

\begin{tabular}{|c|c|c|c|c|}
\hline Complications & $\begin{array}{l}\mathrm{Cu} \\
\mathbf{3 7 5} \\
\text { IUCD } \\
\text { users } \\
\mathrm{n}=\mathbf{1 5 0}\end{array}$ & $\%$ & $\begin{array}{l}\text { CuT } \\
\mathbf{3 8 0 A} \\
\text { IUCD } \\
\text { users } \\
\mathrm{n}=\mathbf{1 5 0}\end{array}$ & $\%$ \\
\hline Fever & 3 & 2 & 3 & 2 \\
\hline $\begin{array}{l}\text { Postpartum } \\
\text { haemorrhage }\end{array}$ & 0 & 0 & 0 & 0 \\
\hline $\begin{array}{l}\text { Lochia with foul } \\
\text { odour/Puerperal } \\
\text { sepsis }\end{array}$ & 1 & 0.6 & 0 & 0 \\
\hline Wound infection & 2 & 1.3 & 3 & 2 \\
\hline $\begin{array}{l}\text { Urinary tract } \\
\text { infection }\end{array}$ & 2 & 1.3 & 1 & 0.6 \\
\hline
\end{tabular}

Distribution of adverse events during each follow-up visit in each IUCD user is shown in Table 3.
Vaginal discharge, pelvic pain and bleeding related problems and common clinical presentation with both type of IUDs during follow up and was significantly reduced at 12 months. There was very low pelvic infection rate in both the users.

Both IUCDs provided adequate protection against pregnancy with no increased risk of infection. At each follow up visit IUCD strings were examined for its visibility. Presence of IUD was confirmed by USG in cases of non-visibility of IUCD strings.

Table 4 shows percentage of women with visible and missing strings (detectable on USG) at each visit. Strings were visible in only 7 women in Group A and 3 women in Group B at the time of discharge.

Out of 150 women strings were visible in 108(72\%) CUu375 IUCD user and in 77(51.3\%) CuT380A IUCD users at 1 month of IUCD insertion. This difference was significant $(\mathrm{P}<0.05)$ at 1 month of follow up.Strings visibility after intracesarean insertions was $97.1 \%$ in CUu375 IUCD user compared to $72.3 \%$ in the other group at 12 month.

Table 3: Distribution on the basis of adverse events at 1, 3, 6, and 12 months of IUCD use.

\begin{tabular}{|c|c|c|c|c|c|c|c|c|c|}
\hline \multirow{2}{*}{ Results of follow up } & & \multicolumn{2}{|c|}{1 month } & \multicolumn{2}{|c|}{3 months } & \multicolumn{2}{|c|}{6 months } & \multicolumn{2}{|c|}{12 months } \\
\hline & & $\begin{array}{l}\text { Cu375 } \\
\text { IUCD } \\
\text { users }\end{array}$ & $\begin{array}{l}\text { Cut380a } \\
\text { IUCD } \\
\text { users }\end{array}$ & $\begin{array}{l}\text { Cu375 } \\
\text { IUCD } \\
\text { users }\end{array}$ & $\begin{array}{l}\text { Cut380a } \\
\text { IUCD } \\
\text { users }\end{array}$ & $\begin{array}{l}\text { Cu375 } \\
\text { IUCD } \\
\text { users }\end{array}$ & $\begin{array}{l}\text { Cut380a } \\
\text { IUCD } \\
\text { users }\end{array}$ & $\begin{array}{l}\text { Cu375 } \\
\text { IUCD } \\
\text { users }\end{array}$ & $\begin{array}{l}\text { Cut380a } \\
\text { IUCD } \\
\text { users }\end{array}$ \\
\hline \multirow{4}{*}{$\begin{array}{l}\text { Discharge } \mathrm{P} / \mathrm{V} \\
\text { Bleeding related } \\
\text { problem* }\end{array}$} & $\mathrm{n}$ & 23 & 37 & 25 & 40 & 12 & 15 & 4 & 6 \\
\hline & $\%$ & 15.3 & 24.7 & 16.7 & 26.7 & 8 & 10 & 2.7 & 4 \\
\hline & $\mathrm{n}$ & 18 & 21 & 10 & 16 & 11 & 15 & 13 & 15 \\
\hline & $\%$ & 12 & 14 & 6.67 & 10.7 & 7.3 & 10 & 8.6 & 10 \\
\hline \multirow{2}{*}{ Pelvic pain** } & $\mathrm{n}$ & 15 & 23 & 25 & 44 & 11 & 20 & 6 & 6 \\
\hline & $\%$ & 10 & 15.3 & 16.7 & 29.3 & 7.3 & 13.3 & 4 & 4 \\
\hline \multirow{2}{*}{$\begin{array}{l}\text { Pelvic } \\
\text { inflammatory } \\
\text { disease/puerperial } \\
\text { sepsis }\end{array}$} & $\mathrm{n}$ & 1 & 0 & 0 & 0 & 1 & 2 & 0 & 0 \\
\hline & $\%$ & 0.7 & 0 & 0 & 0 & 0.7 & 1.3 & 0 & 0 \\
\hline \multirow{2}{*}{$\begin{array}{l}\text { Other } \\
\text { complaints } * * *\end{array}$} & $\mathrm{n}$ & 12 & 34 & 21 & 16 & 17 & 18 & 14 & 13 \\
\hline & $\%$ & 8 & 22.7 & 14 & 10.7 & 11.3 & 12 & 9.3 & 8.7 \\
\hline \multirow{2}{*}{ Pregnancy } & $\mathrm{n}$ & 0 & 0 & 0 & 0 & 1 & 0 & 0 & 1 \\
\hline & $\%$ & 0 & 0 & 0 & 0 & 0.7 & 0 & 0 & 0.7 \\
\hline
\end{tabular}

*Included only those women who complained bleeding problem for the first time and those who continue to have problem after medical treatment.

** Included only those women who complained of pelvic pain for the first time and those who continue to have problem after medical treatment.

*** Other complaints include weakness, weight loss, fatigue, generalized body pain etc

There was significant difference for strings visibility in intracesarean insertion of IUCD at 1 year of follow up $(\mathrm{p}<0.05)$. The Gross cumulative continuation rates were $86 \%$ in women with Cu375 IUCD insertions. There were $6.7 \%$ expulsions and $7.3 \%$ removals in this group. The Gross cumulative Continuation rate was $89.3 \%$ in CuT380A IUCD users. There were $4 \%$ expulsion and $6.7 \%$ removal in this group in Table 5. Eighty two 
percent and $86.7 \%$ of the women were satisfied with Cu375 IUCD and CuT380A IUCD respectively. On statistical analysis the difference in level of satisfaction with IUCD use was not statistically significant $(p=0.857)$ by chi square tests.

Table 4: Visualization of strings of IUCD during follow up.

\begin{tabular}{|c|c|c|c|c|c|c|c|c|}
\hline \multirow[b]{2}{*}{$\begin{array}{l}\text { Result of follow } \\
\text { up }\end{array}$} & \multicolumn{2}{|c|}{1 month, n (\%) } & \multicolumn{2}{|c|}{3 months, n (\%) } & \multicolumn{2}{|c|}{6 months, n (\%) } & \multicolumn{2}{|c|}{12 months, n (\%) } \\
\hline & $\begin{array}{l}\text { CU375 } \\
\text { IUCD } \\
\text { users }\end{array}$ & $\begin{array}{l}\text { CuT380A } \\
\text { IUCD } \\
\text { users }\end{array}$ & $\begin{array}{l}\text { CU375 } \\
\text { IUCD } \\
\text { users }\end{array}$ & $\begin{array}{l}\text { CuT380A } \\
\text { IUCD } \\
\text { users }\end{array}$ & $\begin{array}{l}\text { CU375 } \\
\text { IUCD } \\
\text { users }\end{array}$ & $\begin{array}{l}\text { CuT380A } \\
\text { IUCD } \\
\text { users }\end{array}$ & $\begin{array}{l}\text { CU375 } \\
\text { IUCD } \\
\text { users }\end{array}$ & $\begin{array}{l}\text { CuT380A } \\
\text { IUCD } \\
\text { users }\end{array}$ \\
\hline No. of women & 150 & 150 & 146 & 147 & 145 & 144 & 136 & 137 \\
\hline String visibility & $108(72)$ & $77(51.3)$ & $121(82.9)$ & $88(59.9)$ & $134(92.4)$ & $91(63.2)$ & $132(97.1)$ & $99(72.3)$ \\
\hline $\begin{array}{l}\text { String not visible } \\
\text { on PS but visible } \\
\text { on USG }\end{array}$ & $42(28)$ & $73(48.7)$ & $25(17.1)$ & $59(40.1)$ & $11(7.6)$ & $53(36.8)$ & $4(2.9)$ & $38(27.7)$ \\
\hline $\begin{array}{l}\text { String not visible } \\
\text { due to expulsion }\end{array}$ & 0 & 0 & 0 & 0 & $2(1.4)$ & $2(1.4)$ & $2(1.5)$ & 0 \\
\hline $\begin{array}{l}\text { String visible due } \\
\text { to partial expulsion }\end{array}$ & $3(2)$ & $1(0.67)$ & $1(0.7)$ & $3(2.1)$ & $2(1.4)$ & 0 & 0 & 0 \\
\hline
\end{tabular}

Table 5: Overall continuation of IUCDs at 12 month follows up visit.

\begin{tabular}{|c|c|c|c|c|c|c|c|c|c|c|c|}
\hline & \multirow[t]{2}{*}{ Follow up } & \multicolumn{2}{|c|}{1 month } & \multicolumn{2}{|c|}{3 months } & \multicolumn{2}{|c|}{6 months } & \multicolumn{2}{|c|}{12 months } & \multicolumn{2}{|c|}{ Total } \\
\hline & & $\mathrm{n}$ & $\%$ & $\mathrm{n}$ & $\%$ & $\mathrm{n}$ & $\%$ & $\mathrm{n}$ & $\%$ & $\mathrm{n}$ & $\%$ \\
\hline \multirow{4}{*}{$\begin{array}{l}\text { Cu375 } \\
\text { IUCD } \\
\text { users }\end{array}$} & Expulsions & 3 & 2 & 1 & 0.7 & 4 & 2.7 & 2 & 1.3 & 10 & 6.7 \\
\hline & Removals & 1 & 0.7 & 0 & 0 & 5 & 3.3 & 5 & 3.3 & 11 & 7.3 \\
\hline & Discontinuations & 4 & 2.7 & 1 & 0.7 & 9 & 6 & 7 & 4.7 & 21 & 14 \\
\hline & Continuations & 146 & 97.3 & 145 & 96.7 & 136 & 90.7 & 129 & 86 & 129 & 86 \\
\hline \multirow{4}{*}{$\begin{array}{l}\text { CuT380A } \\
\text { IUCD } \\
\text { users }\end{array}$} & Expulsions & 1 & 0.7 & 3 & 2 & 2 & 1.3 & 0 & 0 & 6 & 4 \\
\hline & Removals & 2 & 1.3 & 0 & 0 & 5 & 3.3 & 3 & 2 & 10 & 6.7 \\
\hline & Discontinuations & 3 & 2 & 3 & 2 & 7 & 4.7 & 3 & 2 & 16 & 10.7 \\
\hline & Continuations & 147 & 98 & 144 & 96 & 137 & 91.3 & 134 & 89.3 & 134 & 89.3 \\
\hline
\end{tabular}

Overall $84.7 \%$ of the women were satisfied with the treatment and $60 \%$ to an extent that they would like to recommend it to others whereas $15.3 \%$ were not satisfied at all either due to adverse events or spontaneous expulsion of IUCD. (Table 6).

\section{DISCUSSION}

The significance of healthy spacing of pregnancy in India is emphasized by the fact that approximately $27 \%$ of births occur in less than 24 months after previous birth. Nearly $61 \%$ of births occur within the recommended birth to birth interval of 36 months. ${ }^{3}$

The intrauterine device is an effective long lasting and reversible method of birth control., ${ }^{3,9,10}$ The insertion of IUCDs is now gaining popularity as a method of postpartum contraception worldwide. The Indian Government is also focusing programmatic attention to postpartum IUCD insertion. Immediate postplacental IUCD insertion (PPIUCD) during caesarean section provides a good opportunity to achieve long term contraception with minimal discomfort to the women. ${ }^{7}$ It is being increasingly practiced after reported safety and lower expulsion rates following intracaesarean IUCD insertion. ${ }^{11-13}$

Immediate postpartum insertion of IUCDs has been practiced in China since 1975. In a controlled trial comparing intracaesarean IUCD insertions at caesarean section with non-intervention controls, only a few complications were reported, and no difference was found in puerperal morbidity or infection. ${ }^{12}$

Infectious morbidity in the present study was consistent with previous reports by Celen et al., and Eroglu et al., but lower than that reported by Bhutta et al. ${ }^{4,11,14}$

In the present study 8 women with $\mathrm{Cu} 375$ arm developed postoperative complication as against 7 women with $\mathrm{CuT}$ $380 \mathrm{~A}$ arm. No significant difference was observed between the febrile morbidity, puerperal sepsis or amount of bleeding/lochia in the first postoperative week in both the groups. The duration of postoperative hospitalization did not vary either. The only one case with puerperal sepsis required higher antibiotics and resuturing with removal of Cu375 IUCD. This woman did not give the history of prolonged leaking per vaginum (Table 2). 
Follow-up care after immediate PPIUCD insertions is a vital component for ensuring detection of early expulsions and higher continuation rates. Close clinical follow-up can ensure proper placement and reinsertion of IUCD if expulsion has occurred. Current guidelines recommend that asymptomatic IUD users should return for a follow-up visit after 3-6 weeks of insertion. ${ }^{15}$ In most of the studies, first follow up visit was scheduled between 4-6 week except in study by Dahlke et al with first visit at two weeks 16 In the present study, follow up was scheduled at 1, 3, 6, and 12 months of IUCD insertion. None of the women were lost to follow up; this emphasizes the significance of good counselling and constant contact with the clients, to ensure optimal follow up. The observed decrease in the number of women during follow up visits was due to the terminal events like expulsion, removal, and failure. More than $90 \%$ women successfully completed 12 months follow up in both the groups.

Vaginal discharge, pelvic pain and bleeding related problems are common clinical presentation with both type of IUDs during follow up and was significantly reduced at 12 months. Pelvic infection rate is low in post placental insertion of $\mathrm{Cu} 375$ and CuT380A. Post placental IUCD (Cu 375 and CuT380A) insertion provides adequate protection against pregnancy with no increased risk of infection.

According to Beltagy et al there was no significant difference between CuT380A IUD users and Multiload 375 IUD users regarding bleeding abnormalities, pelvic pain, or excessive vaginal discharge following PPIUCD. ${ }^{17}$

Visibility of strings increased in successive follow up visits. Strings were visible in $72 \%$ of subjects at 1 month, $82.9 \%$ at 3 months, and $92.4 \%$ at the end of 6 month, which increased to $97.1 \%$ at the end of 1 year in $\mathrm{Cu} 375$ insertions. In CuT380A insertions, strings were visible in $51.3 \%$ at 1 month, $59.9 \%$ at 3 months, $63.2 \%$ at 6 month and $72.3 \%$ of subjects at 1 year. String visibility was more in $\mathrm{Cu} 375$ insertions as compared to CuT380A insertions. This difference was highly significant $(\mathrm{P}=0.000)$ at 1 month of follow up, but by the end of 1 year the difference was not statistically significant $(\mathrm{P}=0.379)$ (Table 4).

The length of nylon thread in $\mathrm{Cu} 375$ was 19.4 centimeters whereas the length of the thread in CuT380A was 11.5 centimeters. This could be the reason for the early visibility of the strings in majority of subjects in whom Cu375 were inserted immediately after expulsion of placenta. The fundus of the uterus corresponds to fivemonth pregnant uterus size, hence IUD strings were not visible in CuT380A group and some women in $\mathrm{Cu} 375$ group. Non-visibility of strings in CuT380A at the time of insertions reassures provider about fundal placement of IUD.
In this study missing string was more frequent in $\mathrm{Cu} 380 \mathrm{~A}$ group as compared to $\mathrm{Cu} 375$ IUD insertions during cesarean sections. Visibility of strings is also important as it provides ease of removal of IUCD. In order to solve the problem Nelson A et al reported the study where they provided tailstrings of sufficient length and strength so that if at any time a complication developed (infection, bleeding, etc.), device could easily be removed. ${ }^{18}$ Expulsion of IUCD is an important factor affecting efficacy of the device. Maximal expulsions in previous studies have been detected during the first follow up visit. $^{11,13,19}$ In the present study expulsion Our observations are similar to those of Chi et al. However, Celen et al have reported a higher cumulative expulsion rate of 17.6 per 100 women per year. ${ }^{14,19}$

In the present study expulsion rates of CuT380A IUD at 12 months was $4 \%$ and of Cu375 was $6.7 \%$ with overall expulsion rate of $5.3 \%$. There were more expulsions in $\mathrm{Cu} 375$ users as compare to CuT380A users, but the difference was not statistically significant. (Table 5)

Similar results were seen by Henrique J etal109. Our results were in accordance with Arowojolu, Lara R and Eroglu for PPIUCD insertions, which reported lower expulsions in $\mathrm{CuT380A}$ than $\mathrm{Cu} 375$ with interval insertions also. ${ }^{11,20,21}$

String visibility was more in $\mathrm{Cu} 375$ insertions as compared to CuT380A insertions. This difference was highly significant $(\mathrm{P}<0.05)$ at 1 month of follow up and even at 1 year follow up.

IUCD removal rate in present study was $7 \%$. Removal rate in was $7.3 \%$ in $\mathrm{Cu} 375$ users and $6.7 \%$ in CuT380A users. No statistically significant difference was found in rate of IUCD removal in both the groups $(\mathrm{p}=0.7788)$ (Table 5). Similar results were observed in other studies also. 22, 23 In contrary Wen $\mathrm{J}$ et al reported the removal rate (for bleeding and/or pain) and PID for TCu380A to be higher than those of MLCu375. ${ }^{22}$

Psychosocial causes accounted for $52.4 \%$ removals in present study. After 6 months commonest reason for removal was medical (pain and bleeding and pelvic infection). Medical cause accounted for $47.6 \%$ of total removals in present study. Removal for pelvic pain, infection or menorrhagia accounted for $4(2.8 \%)$ IUCD removals in Cu375 users and 4 (2.8\%) in CuT380A users. This was in accordance with study by Lara $\mathrm{R}$ et al. in which the removal rates for bleeding and pain were 4.9 and 4.8 and the removal rates for nonmedical reason were 3.7 and 4.9 respectively for $\mathrm{Cu} 375$ and $\mathrm{CuT380A}$ users respectively. ${ }^{21}$

In present study 12 months continuation rates are $86 \%$ and $89.3 \%$ in Cu375 and CuT 380A IUCD respectively. Continuation rate were more in CuT380A due to less number of expulsions and removals than $\mathrm{Cu} 375$ (Table 5). According to recent literature continuation rates of 
Cu375 and CuT380A is more in caesereans than vaginal delivery. This was mostly due to low expulsions and low removal rates in caesarean section patients. ${ }^{23}$ The degree of satisfaction with IUCD at the end of 12 months of use was assessed. It was observed that $84.7 \%$ of the women were satisfied with the treatment and $60 \%$ to an extent that they would like to recommend it to others whereas $15.3 \%$ were not satisfied at all either due to adverse events or spontaneous expulsion of IUCD (Table 6).

Table 6: Level of satisfaction at the end of 1 year or time of discontinuation.

\begin{tabular}{|c|c|c|c|c|c|c|}
\hline \multirow[t]{2}{*}{ Satisfaction } & \multicolumn{2}{|c|}{$\begin{array}{l}\text { Cu375 } \\
\text { IUCD users } \\
\mathbf{N}=\mathbf{1 5 0}\end{array}$} & \multicolumn{2}{|c|}{$\begin{array}{l}\text { CuT380A } \\
\text { IUCD users } \\
\mathbf{N}=150\end{array}$} & \multicolumn{2}{|c|}{$\begin{array}{l}\text { Total, } \\
\mathbf{N}=\mathbf{3 0 0}\end{array}$} \\
\hline & No. & $\%$ & No. & $\%$ & No. & $\%$ \\
\hline Sat & 124 & 82.7 & 130 & 86.7 & 254 & 84.7 \\
\hline Unsatisfied & 26 & 17.3 & 20 & 13.3 & 46 & 15.3 \\
\hline
\end{tabular}

\section{CONCLUSION}

Post placental intracaesarean insertion of Cu375 IUCD or CuT380A IUCD is safe, reversible, long term, convenient method of contraception with low expulsion and high continuation rates. There was no significant difference between the IUCDs regarding safety, efficacy and continuation rates.

\section{Funding: No funding sources}

Conflict of interest: None declared

Ethical approval: The study was approved by the Institutional Ethics Committee

\section{REFERENCES}

1. Barett G, Peacock J, Victor CR, Manyonda I. Caesarean section and postnatal sexual health. Birth. 2003;32(4):306-11.

2. Mishra N, Dalal N, Joshi V. Intrauterine Device Insertion during Caesarean Section- A Boon for Rural Women. IOSR-JDMS. 2013;8(3):21-3.

3. Postpartum IUCD Reference Manual, New Delhi: Family Planning Division, Ministry of Health and Family Welfare, Government of India. 2010. Available

at: http://www.nrhmtn.gov.in/modules/PPIUCD\%20Ref erence\%20Manual.pdf

4. Bhutta SZ, Butt IJ, Bano K. Insertion of intrauterine contraceptive device at caesarean section. J Coll Physicians Surg Pak. 2011;21(9):527-30.

5. Levi E, Cantillo E, Ades V, Banks E, Murthy A. Immediate postplacental IUCD insertion at caesarean delivery: a prospective cohort study. Contraception. 2012;86(2):102-05.

6. Shukla M, Qureshi S, Chandrawati. Post-placental intrauterine device insertion--a five-year experience at a tertiary care centre in north India. Indian J Med Res. 2012;136(3):432-5.
7. Kapp N, Curtis KM. Intrauterine device insertion during the postpartum period: a systematic review. Contraception. 2009;80(4):327-36.

8. Cwiak C, Gellasch T, Zieman M. Peripartum contraceptive attitudes and practices. Contraception. 2004;70(5):383-6.

9. Thonneau PF, Almont T. Contraceptive efficacy of intrauterine devices. Am J Obstet Gynecol. 2008;198(3):248-53.

10. Kulier R, O'Brien PA, Helmerhorst FM, Usher-Patel $\mathrm{M}$, D'Arcangues C. Copper containing, framed intrauterine devices for contraception. Cochrane Database Syst Rev. 2007;(4):CD005347.

11. Eroglu K, Akkuzu G, Vural G, Dilbaz B, Akin A, Takin L, et al. Comparison of efficacy and complications of IUD insertion in immediate postplacental/early postpartum period with interval period: 1-year follow-up. Contraception. 2006;74(5):376-81.

12. $\mathrm{Xu} J X$, Reusché $\mathrm{C}$, Burdan A. Immediate postplacental insertion of the intrauterine device: a review of Chinese and the world's experiences. Adv Contracept. 1994;10(1):71-82.

13. Celen S, Möröy P, Sucak A, Aktulay A, Daniman N. Clinical outcomes of early postplacental insertion of intrauterine contraceptive devices. Contraception. 2004;69(4):279-82.

14. Çelen, Sucak A, Yıldız Y, Danıman N. Immediate postplacental insertion of an intrauterine contraceptive device during cesarean section. Contracep. 2011;84(3):240-43.

15. Long-acting reversible contraception the effective and appropriate use of long-acting reversible contraception. Regents Park, London: National Collaborating Centre for Women's and Children's Health Commissioned by the National Institute for Health and Clinical Excellence; 2005. October 2005.

16. Dahlke JD, Terpstra ER, Ramseyer AM, Busch JM, Rieg T, Magann EF. Postpartum insertion of levonorgestrel--intrauterine system at three time periods: a prospective randomized pilot study. Contracep. 2011;84(3):244-8.

17. El Beltagy NS, Darwish EA, Kasem MS, Hefila NM. Comparison between Cupper T380 IUD and Multiload 375 IUD in early post-partum insertion. Middle East Fertil Soc J. 2011;16(2):143-8.

18. Nelson AL, Chen $\mathrm{S}$, Eden $\mathrm{R}$ intraoperative placement of CuT380intrauterine contraceptive devices in women undergoing elective caserean. Contraception. 2009;80(1):81-3.

19. Chi IC, Zhou SW, Balogh S, NG K. Post-cesarean section insertion of intrauterine devices. Am J Public Health. 1984;74(11):1281-2.

20. Arowojolu AO, Otolorin EO, Ladipo OA. Performances of copper $\mathrm{T} 380 \mathrm{~A}$ and multiload copper 375/250 intrauterine contraceptive devices in a comparative clinical trial. Afr J Med Med Sci. 1995;24(1):59-65.

21. Lara R, Sanchez RA, Aznar R. Application of intrauterine device through the incision of the 
cesarean section. Gynecol and Obstet Mexico. 1989;57:23-7.

22. Wen Jin, Ying Li, You-ping Li, Li Wang, Comparative safety and effectiveness of TCu380A versus MLCu375: A systematic review of randomized trials $\mathrm{J}$ Evidence-Based Med. 2009;2,9(4):226-41.

23. Kumar M, Kumar M, Aggarwal P, Gangania A, Dewan R. A study to evaluate and compare the expulsion and continuation rates of post placental insertion of $\mathrm{Cu} 375$ and $\mathrm{CuT} 380 \mathrm{~A}$ in Indian women at a premier hospital in New Delhi, India. Int $\mathbf{J}$ Reprod Contracept Obstet Gynecol. 2017;6(9):39924000 .

Cite this article as: Divya, Dewan R, Clinical outcome of post placental copper T380A and copper 375 IUCD insertion in women delivering by caesarean section. Int J Reprod Contracept Obstet Gynecol 2018;7:3731-7. 